\title{
Sistema de Moda na Blumenau de 1850-1890: Confrontos e Relações
}

Projeto de Pesquisa PROBIC/UDESC: Brasil por suas aparências - Uma história da moda. Vol.2. Bolsista Voluntária: Paula Consoni. Orientadora: Mara Rúbia Sant'Anna.

O presente artigo baseia-se no meu Trabalho de Conclusão de Curso, cuja defesa ocorreu no dia 4 de Julho de 2008, e dá continuidade ao meu interesse por pesquisar o período histórico com o qual trabalhei no projeto de pesquisa de iniciação cientifica "Brasil por suas aparências - Uma história da moda" referente ao volume do período Imperial. Por este motivo, procurei a professora Sueli Petry, diretora do patrimônio histórico museológico de Blumenau, pois nos conhecemos no Simpósio Nacional de História em 2007 e na ocasião ela havia comentado a respeito do acervo de trajes do Museu da Família Colonial datados do século XIX, além de revistas e fotografias da época constantes no Arquivo Histórico da cidade.

O estudo que se segue discorrerá a respeito das tendências de moda do período de 1850 a 1890 em âmbito europeu, nacional (com foco na capital do império) e catarinense (Desterro, em especial) com o objetivo de delinear quadro comparativo com as práticas vestimentares de Blumenau. Tendo em vista, ainda, o acesso a informação de moda, o comércio e os espaços de sociabilidade oferecidos como formas possíveis de inserção das roupas do acervo, objetos principais do meu Trabalho de Conclusão de Curso, no contexto do sistema de moda ${ }^{1}$ da época.

Entende-se por necessário especificar o comprometimento de interpretação da vestimenta como uma "linguagem simbólica, um estratagema de que o homem sempre se serviu para tornar inteligível uma série de idéias como o estado emocional, as ocasiões sociais, a ocupação ou o nível do portador" (SOUZA, 1987, p.125). Sendo que, a partir da constituição do ethos moda, o vestuário dos grupos sociais de elite foi tendo acrescida a valoração positiva do novo, ampliando consideravelmente as possibilidades destes trajes de interferir na constituição das subjetividades e nas relações sociais. (SANT’ANNA, 2007.)

A importância dessa abordagem se dá no entendimento do objeto consumido como ponto de partida para interpretar as articulações sociais em que ele se insere, por considerar que os objetos "absorvendo os sujeitos, mediatizam sua integração ao mundo, agenciando subjetividades, promovendo o acesso ao espaço, à temporalidade, aos outros e a si mesmo"

\footnotetext{
${ }^{1}$ Termo refere-se às etapas cíclicas da concepção de um produto de moda até a sua comercialização. Os processos analisados neste estudo foram: a matéria-prima (tecidos e aviamentos), tendências de moda, técnicas de construção (modelagem e confecção), locais de comercialização e exibição.
} 
(SANT'ANNA, 2007, p.61). Segundo Baudrillard (2001) os objetos são tanto expressão como construtores dos espaços, da temporalidade e dos sujeitos.

Sant'Anna destaca o consumo como a "integração ao sistema de interpretação do mundo" (2007, p.59).

\footnotetext{
A lógica social do consumo (...) se encontra na produção e manipulação dos significantes sociais, vinculada aos processos de significação e comunicação, o que viabiliza suas práticas, e, por outro lado, aos processos de classificação e diferenciação social, hierarquizando os objetos e seus signos socialmente (2007, p.59).
}

Para alcançar o objetivo proposto, no que diz respeito ao estudo das tendências e da estrutura do comércio europeu e nacional, buscou-se o artigo intitulado "Feminilidades e consumos no Brasil Imperial” publicado nos Anais do XXIV Simpósio Nacional de História em co-autoria com a Prof ${ }^{\mathrm{a}} \mathrm{Dr}^{\mathrm{a}}$ Mara Rúbia Sant'Anna. Quanto a Colônia Blumenau, as revistas de moda originais de Berlim "Die Modenwelt" e "Victoria - Illustrierte Muster und Modezeitung" tiveram especial importância na esfera da informação de moda, já as fotografias de mulheres da colônia ofereceram o entendimento de como estas informações eram efetivamente consumidas. As memórias dos imigrantes transcritas em livros e as cartas aos parentes na Alemanha trouxeram dados valiosos no que tange a realidade do comércio, do transporte dos artigos de vestuário encomendados e os locais de convívio social como palcos possíveis de exibição.

\subsection{COMÉRCIO}

\subsubsection{Europa versus Rio de Janeiro}

Em 1850, a cidade do Rio de Janeiro oferecia um espaço de comércio suficientemente adequado para a prática dos novos hábitos de consumo que se tornavam imprescindíveis ao papel social que a mulher, de determinados grupos sociais, realizava na projeção de seus maridos. Tais práticas estavam no exercício da escolha e da compra de variados artigos que a economia favorável e as importações ofertavam e, logo, na busca dos artigos de luxo, no domínio de seus usos e na capacidade de avaliá-los. 
Em matéria de moda a "boa sociedade" carioca adotou a França como referência. Ao longo da segunda metade do século, pelos dados do Almanaque Laemmert ${ }^{2}$ o número de lojas que vendiam produtos franceses aumentou, sendo sua grande maioria localizada na Rua do Ouvidor. Se em 1850 eram 22 lojas de moda e fazendas francesas, em 1880, este número subiu para 110 lojas (RAINHO, 2002, p.53).

Pensando estes espaços de comércio em contraponto com o que era oferecido na Europa, propõe-se um comparativo entre o bairro comercial da moda em Londres - West End e sua mais importante loja de departamentos - a Harrod's Store e a Rua do Ouvidor, espaço de comércio de moda carioca, com o estabelecimento comercial: Notre Dame de Paris.

O bairro londrino era conhecido das mais requintadas consumidoras brasileiras e tê-lo freqüentado, especialmente para vestir seus maridos e filhos, atribuía-lhes prestígio social e, especialmente, a auto-compreensão que eram brasileiras, mas nem tanto. A Harrod's Store um "altar da moda" ficava em um prédio com dois andares e tinha lojas adjacentes acopladas, dispunha de salas de repouso para os clientes cansados de percorrer seus corredores, além de vitrines com iluminação a gás, caixas registradoras, escada rolante (CHARLOT, 1993). Enfim a mais moderna tecnologia estava presente na Harrod's e conhecer estes detalhes, citá-los nas comparações feitas às lojas brasileiras era bastante significativo para a afirmação da condição de elite das mulheres em questão.

Assim como o estabelecimento comercial londrino, a Notre Dame de Paris era uma loja de departamento e por este motivo "oferecia uma dupla vantagem aos clientes. Vendia produtos manufaturados a preços vantajosos e concentrava em um único local toda uma variedade de produtos e serviços" (CHARLOT, 1993, p.64). A partir da descrição feita por Joaquim Manuel de Macedo sobre o comércio do Rio de Janeiro percebem-se outras semelhanças entre os estabelecimentos comerciais: a amplitude e a iluminação.

Nas palavras do romancista, eram "quatro lojas como independentes, e cada uma com duas vidraças de exposição e sua porta de entrada" (MACEDO) ambas comunicando-se e acabando "no fundo completamente abertas para a galeria central de exposição de vestidos, de toilettes, etc" (MACEDO) em um total de doze portas e vidraças. Quantos as "casinhas térreas", tinham a frente "iluminada na linha superior por numerosa série de bicos de gás" (MACEDO).

Não há dados, porém, de outras características que igualem as duas lojas. Porém, o que importa, é que o sucesso da Notre Dame de Paris chegou ao século XX representando

\footnotetext{
${ }^{2}$ Obra que a partir de 1840 publicava anualmente uma lista das fábricas, oficinas, artesanatos e lojas registradas pelo governo do Rio de Janeiro.
} 
requinte e ambiente de consumo das elites cariocas exatamente por ser um centro comercial brasileiro com cara européia.

Tanto passeando pela Rua do Ouvidor, quanto pela West End, a elite elaborava semelhantes formas de parecer e, mesmo que não gozasse das mesmas tecnologias, a sociedade carioca a consumia como forma de entretenimento e entretia-se para ser visto.

Contudo, se pensarmos essa mesma questão em relação as localidades distantes da corte, sem nenhum surto econômico que pudesse aproximar a elite local da almejada Europa, observa-se que o consumo do espelho europeu era mais deficitário.

\subsubsection{Desterro}

Enquanto outras províncias quebraram a hegemonia de Portugal, já nos fins do século XVIII, e buscaram assemelhar-se ao máximo da estética francesa, Santa Catarina e sua capital Desterro, a atual Florianópolis, não mudou seu parâmetro cultural de beleza e bom gosto, mantendo-se atrelada à fidalguia portuguesa de onde procedia.

A principal rua do comércio de moda em Desterro era a Rua do Príncipe, atual Felipe Schmidt. Contudo, diferente da sociabilidade cortesã carioca que tinha por hábito o passeio pelo comércio, na antiga Florianópolis, o mais comum era as senhoras mandarem seus serviçais buscarem amostras dos tecidos nas lojas e faziam suas escolhas nas suas casas, entre sua parentela e empregados. As damas catarinenses, um grupo muito restrito em comparação ao de outras capitais provinciais, pouco iam ao comércio e não haviam desenvolvido o apreço pelas sociabilidades à lá francesa que a expansão da industrialização dos produtos destinados à aparência corporal produziu.

Fato que também revela a permanência da moralidade portuguesa pós-medieval na sociedade desterrense do século XIX é o uso predominante do preto nas roupas femininas e masculinas. "Não havia senhora casada, de qualquer idade, que não tivesse o seu vestido preto, de seda ou de qualquer outra fazenda" (CABRAL, 1979, p.322), pois a cor era considerada "distinta, severa, austera, emprestava dignidade, revelava posição, berço, educação, infundia respeito" (CABRAL, 1979, p.322).

Já nos detalhes dos trajes é que ocorriam algumas modificações, seguindo com certo atraso as novas tendências de moda que chegavam à Ilha de Santa Catarina no corpo de alguma ilustre visitante. O memorialista Oswaldo de Cabral ao descrever um vestido feminino fala desta preocupação: 
É um vestido (...) decotado para não deixar à mostra uma nesga dos seios e o discreto vale entre eles, ou então, conforme a moda da ocasião, afogadinho até o pescoço, com golinha de rendas e fitas. (...) O mais dependia da moda: - apanhados na parte superior, com muito pano, muita fita ou muita renda, enobrecendo o volume (CABRAL, 197, p.334).

Se Desterro valorizava mais os costumes portugueses herdados do que os novos hábitos que a Corte instituída sugeria, o que dizer a respeito da sociedade em formação na Colônia Blumenau, onde famílias despatriadas viam no trabalho e no lucro a oportunidade de recomeço, sobrevivência e enriquecimento.

\subsubsection{Colônia Blumenau}

Entramos no espaço que servia de venda e tomamos conhecimento do local. Sua instalação era modesta e os mantimentos que vimos estavam deteriorados em conseqüência da demora do transporte. Havia ainda miudezas como: linhas, agulhas, isqueiros, pólvora, chumbo, pregos, etc. Isto era praticamente tudo, porém ainda havia roupas grotescas de algodão para o trabalho, e tecido de lã azul e vermelho para o inverno. Todavia, não pensem que se conseguia comprar sempre esses artigos, pois ora faltava uma, ora outra coisa durante meses, às vezes, até o sal, tudo dependia das circunstancias e das condições climáticas (KLEINE, 2000, p.17).

Nas palavras de Kleine sobre a experiência vivida, no ano de 1856, percebe-se o quanto deficitário era o comércio logo no surgimento de Blumenau e que o empecilho para a aquisição de produtos diversos estava especialmente na dificuldade de acesso à região.

Dados referentes ao ano de 1859 indicam a existência de menos de sete quilômetros de ruas "carroçáveis" e quase onze quilômetros de estradas para cavaleiros e pedestres (SANTIAGO, 2001). Já no ano de 1869, marcado por um fomento da infra-estrutura da Colônia e a multiplicação por seis do número de habitantes, passaram para 63 e 220 quilômetros as ruas "carroçáveis" e as estradas para pedestres, respectivamente, isso aliado as vias de ligação com o Planalto (SANTIAGO, 2001). O ano de 1879 foi festejado pela chegada do vapor Progresso e a abertura dos primeiros trechos de estrada para Lages (SANTIAGO, 2001).

A primeira casa comercial, Meyer \& Spierling, surgiu em 1855 e operou até 1884 . O segundo estabelecimento de comércio foi fundado por Pocópio Hoeschl em 1864, em Gaspar. Em 1874, as maiores exportadoras eram a H.Probst, a Scharader e a Salinger (SANTIAGO, 2001).

Viajante estrangeiro, no ano de 1891, escreveu sobre as condições de transporte definindo-as como "incrivelmente complicadas" (BALLOD apud WILLEMS, 1946, p.169) 
revela que a dificuldade não estava somente em receber os produtos, mas também de enviálos ao restante do país.

O colono de Blumenau é obrigado a levar, de carroça, os seus produtos, em viagem de um a dois dias, à cidade; daí eles são transportados em um pequeno vapor fluvial, de $90 \mathrm{~cm}$. De calado, ao porto de Itajaí. Segue outra baldeação e um navio leva os produtos à capital, Desterro, onde há alfândega. Alí pagam-se os impostos aduaneiros e depois os produtos são carregados por outro vapor... Assim as despesas até o Rio de Janeiro são duas ou três vezes mais altas do que as que se pagam da Europa ao Brasil (BALLOD apud WILLEMS, 1946, p.169).

Em carta datada de 1887, endereçada à irmã e ao cunhado na Alemanha, Franz Meyer escreveu: "As roupas devido a tarifa alfandegária são quase impossíveis de pagar. O que vocês pagam 1 Marco custa para nós 5 a 6 Marcos"(MEYER,1887). Assim que, os colonos conviviam com um comércio interno carente de produtos variados, além das dificuldades de acesso as outras localidades e os altos preços gerados pelas tarifas alfandegárias.

Alternativa encontrada para a aquisição de artigos do vestuário e acessórios, além de matéria-prima como aviamentos e tecidos, era a encomenda aos parentes na Alemanha. Trechos de cartas enviadas aos familiares mostram claramente essa necessidade:

Para finalizar, quero fazer ainda algumas encomendas que vocês, por favor, arranjem para mim. Uma peça de algodão fino e branco para duas dúzias de camisas para mim, junto com uma peça de linho fino para peitilho e gola para estas camisas. Um ferro bem grande de passar roupa e meio-quilo de linha de algodão para minhas meias. Para seis janelas de divisória chita brilhante, mas de cor firme para não desbotar com o sol forte daqui. E chita brilhante para forrar um sofá. Alguns cortes de chita para vestidos de casa para minha mulher. Um pedaço de pano de linho. Retrós, linha de seda, lã-sefira em várias cores (Kannova). Sutach para enfeite de vestidos na barra e grega. Alguns lenços brancos de linho para mim e minha mulher. Agulhas de costura e agulhas de tricô. Fazenda listrada para aventais de trabalho, e mais fina para usar em casa (SALLENTIEN, 1997).

Nós já estamos alegres e contentes, principalmente minha esposa Augusta pelos vestidos azuis de Tibet [qualidade do tecido] (MEYER, 1862).

Tal opção não era livre de problemas, fato que pode ser percebido em carta datada de 1863. Em primeiro trecho, lê-se da dificuldade em receber as encomendas e acertar o tamanho das peças. De qualquer forma, o contentamento pelo recebimento e a gratidão parecem maiores que estes infortúnios.

Finalmente recebemos a caixa que com muita dificuldade chegou. O Dr. Blumenau precisou escrever três vezes ao Rio de Janeiro para resolver a situação. Tudo aqui é muito dificultoso e distante. Os objetos chegaram em bom estado, lamentamos somente que nem tudo serviu bem. As botinas de fazenda para minha esposa serviu 
bem, as de couro também. As minhas botas de couro apertam um pouco as outras servem. Ao Fritz não servem nenhuma, os dois pares apertam. Como vocês devem saber nós andamos descalços e por isso o pé é largo, e não como na Alemanha. As botinas de fazenda da Augusta também são pequenas, porem ficamos contentes e satisfeitos sobre tudo o que mandaram (MEYER, 1863).

Alternativa apresentada no segundo trecho da carta é a de enviar as encomendas pelos imigrantes que estavam de partida para Blumenau ou por transportadoras, como forma de evitar o pagamento das tarifas alfandegárias.

Prezado cunhado, você pediu que escrevêssemos o que nos custou em frete e direitos alfandegários, aqui devo notificá-lo que por este meio postal os direitos alfandegários encarecem de tal maneira que torna-se mais caro que o próprio valor das coisas que continha a caixa. Seria melhor entregar o que pretende mandar a um emigrante mesmo que isto aconteça com menos freqüência, ou enviar pela firma Wellmann em Bade-Hamburg, estes enviarão o pacote para Santa Catarina e é uma oportunidade de chegar aqui mais rapidamente (MEYER, 1863).

E os problemas estavam também em enviar o pagamento das encomendas:

Isto diz respeito o dinheiro sobre as coisas que vocês mandaram. Vocês não devem pensar que aqui no Brasil é como na Alemanha, somente precisamos ir ao correio onde podemos despachar pacotes e dinheiro com facilidade. Eu já me incomodei com as coisas enviadas, mais do que elas valem (MEYER, 1867).

Logo, a partir da análise das cartas e dos dados historiográficos entende-se que as tantas dificuldades em comprar ou encomendar as roupas e acessórios levavam o colono a necessidade de usar um mesmo artigo por muito tempo. Percebe-se ainda a distância entre a realidade européia e carioca quanto à disponibilidade de artigos e ao hábito do consumo atrelado ao lazer. No que tange a realidade de Desterro, as diferenças no ato de consumir, se comparadas ao Rio de Janeiro e a Europa, perpassavam uma escolha relacionada a uma questão cultural e não a falta de acesso aos artigos em geral, o que era o caso de Blumenau.

Considerando que as encomendas e as ofertas do comércio local eram também de complementos para a confecção dos trajes em Blumenau ou que uma peça poderia ser por várias vezes reformada, qual era o espelho para estas escolhas relacionadas ao vestir? Este entendimento passa pela interpretação do que se usava na Europa e como este uso chegava ao restante do país.

\subsection{TENDÊNCIAS DE MODA}


Souza em "O espírito das roupas: a moda no século dezenove" descreveu as tendências de moda européia para os trajes femininos detalhadamente:

\begin{abstract}
Em 1855 surge a crinolina, introduzida pela imperatriz Eugenia e simbolizando o triunfo da nova era de aço. A mulher passa a ser um triângulo equiilátero, auxiliado pela voga dos chalés e mantilhas que, atirados sobre os ombros e descendo pelas costas, escondem a cintura. Em 1859 a crinolina alcança a sua expansão maior e daí em diante a roda do vestido diminui e a fazenda começa a ser arrepanhada na parte posterior, a parte anterior ficando mais ou menos lisa e acentuando a curva suave das cadeiras. Estamos na idade de ouro dos costureiros (por volta de 1870), e a invenção recente da máquina de costura possibilita a grande elaboração do traje - a maior talvez da história da vestimenta. Em 1884 a anquinha é atirada para cima, assim como os cabelos, e a frente do vestido se torna rígida (1996, p. 63-64).
\end{abstract}

$\mathrm{Na}$ fala da autora transparece a questão da evolução das formas que da crinolina constituída por oito arcos de arame de aço flexível passou a anquinha até as saias longas em forma de sino com cauda, já nos fins do século.

Nas décadas de 1850 e 1860, a extravagância e o exagero serão marcas das roupas femininas: saias com enorme quantidade de tecido distribuída em pregas presas por rendas e borlas, acréscimos de bordados, debruns e festões de tule, além de camadas de babados que deixavam o tecido do vestido pouco visível. Já em 1870 tem-se a volta de certa simplicidade, mesmo que as peças permanecessem ainda bastante volumosas. A década de 1880 é marcada pelo movimento Traje Racional que protestava contra o aspecto não-saudável da moda, em especial, contra o espartilho e as camadas desnecessárias de roupas acolchoadas e barbatanas e pelo retorno da anquinha e da saia sob o corpete-espartilho drapeada horizontalmente, deixando a cintura parecer mais fina.

Faz-se indispensável partir das tendências de moda européia para se interpretar o vestir dos trópicos e, sendo o Rio de Janeiro admirado pelas demais capitais brasileiras por sua maior capacidade de se aproximar do modelo europeu, representava o espelho de consumo do Império nacional.

O viajante estrangeiro Charles d' Expilly, por volta de 1860, narrou sobre as vestes que encontrou nas ruas do Rio de Janeiro usadas pelas "senhoras moldadas pelos usos europeus" que romperam com as velhas tradições portuguesas:

Elas adotaram os chapéus das nossas costureiras, sem esquecer as saias armadas e as anáguas guarnecidas de lâminas de aço pelas quais descobriam de repente um grande carinho. Exagerando ainda mais uma moda das nossas professorinhas, elas usam vestidos ornamentados com sete ou oito fileiras de babado. Há babados da barra até a cintura dos vestidos assim lhes parece mais encorpado, mais rico, e consequentemente de mais bom gosto (apud MAURO, 1991, p. 41-42). 
Na descrição o estrangeiro, numa fala cheia de sutilezas, tanto disse da capacidade das brasileiras, que ele encontrou, de imitar as tendências de moda lançadas na Europa, como, também, ironizou delicadamente o gosto dessas mulheres que exagerando nos babados para exibirem maior riqueza acabavam por distanciar-se daquilo que ele considerava o mais bonito. Também, num outro comentário, reforçou sua impressão de que no Brasil as tendências eram copiadas e usadas de maneira excessiva, salientando que tal opção era inadequada ao corpo da brasileira:

Em seu desejo imoderado de modelar-se segundo as parisienses, as senhoras não se lembram mais de que não se viola em vão a grande lei da harmonia, seja na forma dos vestidos, seja na cor dos tecidos; disso resulta que o pequeno tamanho delas, esmagado por essa sobrecarga de babados, perdeu toda a sua graça (apud MAURO, 1991, p. 41-42).

Dessas faces de uma mesma questão pode-se dizer então que a cópia, na ânsia de ser perfeita, levou aos excessos que, para o olhar estrangeiro, era julgado de mau-gosto, porém, para os "nacionais", esse mesmo excesso apenas servia para reafirmar uma inquestionável similitude à sociedade européia.

Já as mulheres de Blumenau, conviviam com a escassez de produtos diversos e estavam distantes da realidade da capital fluminense onde o gosto pelo excesso era alternativa encontrada para assemelhar-se ao modelo europeu de consumo. Importante recordar que as alemãs da Colônia estavam, já na Europa, longe da sociabilidade da Corte e de todos os seus códigos de agir e consumir, assim que "quanto ao estilo das roupas na região é provável que, tal como na Europa, ele não ultrapassasse a simplicidade dos padrões pequeno-burgueses para os quais a estética contava menos que a ética (honra e poupança) e a economia" (RENAUX, 1995, p.144).

A questão do papel feminino em Blumenau como mão-de-obra importante para o desenvolvimento da região e da família foi amplamente discutida no primeiro capítulo, contudo interpretar nas cartas e fotografias os usos femininos requer a consciência dessa condição socioeconômica e ainda do processo de adaptação que sofriam essas mulheres.

Observa-se nas memórias do colono o retrato da condição de simplicidade, da inadequação das vestes trazidas da Alemanha ao clima tropical e do hábito de não usar sapatos:

Tão simples como a alimentação era também o modo de se vestir. No verão só usavam camisa e calça de algodão e, no inverno, um casaco simples de lã de ovelha. As roupas trazidas da Alemanha em pouco tempo estavam gastas e na maior parte mostravam-se inadequadas para o clima daqui. Sapatos e meias, brevemente, eram dispensados e todos andavam descalços (CONVERSA..., 2007, p.25). 
Dr. Blumenau escreveu em suas anotações da opção pelo uso das sedas nas situações de festividade e, novamente, ressaltou a simplicidade dos trajes na região:

Na Colônia vestem-se de modo mais simples, porém sempre têm bom gosto e raramente deixam de usar lenços de seda e, caso não sejam muito pobres, certamente têm um vestido de seda para os dias de festa (apud PETRY, 2007, p. 105).

Em carta enviada em 15 de agosto de 1860 por Rose Gaertner aos seus avôs na Alemanha revela que os vestidos trazidos ou enviados da Alemanha eram reservados as ocasiões festivas: "Nossos trajes são tão simples. Nós mulheres, vamos com saias e blusas, em geral descalças ou de tamancos naturalmente ficamos alegres. Nos dias de festas, botamos nossas vestes da Alemanha e vamos a Igreja" (SAMETZKY,1860). A expressão "vestes da Alemanha" pode ser interpretada também como sendo um traje típico ou regional alemão. Faz-se importante diferenciar estes significados, pois, conforme se analisará a seguir, há grande diferença entre estes.

No que diz respeito à mudança nos trajes dos imigrantes, um dos fatos mais notáveis é o abandono do uso das vestes típicas, dando continuidade a uma ruptura que eles já estavam realizando no país de origem. O camponês europeu usava estes trajes que carregavam significados e relacionavam o usuário a um grupo especifico, por exemplo: uma mulher solteira deveria usar saia vermelha, cheia de bordados e ornamentos, para sinalizar aos pretendentes a riqueza da propriedade de seu pai. Assim que, as roupas regionais faziam sentido somente quando atreladas a uma sociedade sem moda, onde uma mentalidade coletivista e hierárquica mantinha os costumes e os mitos inalterados e respeitados.

Muito além destes trajes não condizerem com o clima subtropical ou com a situação econômica da maioria dos colonos, já que eram confeccionados com linho e lã, as roupas típicas e os símbolos hierárquicos, com o passar dos anos, perderam as forças para a valoração positiva do novo e do presente e pela interiorização das noções de individualidade e identidade.

Nas memórias da colona Karla Hermann lê-se a respeito de uma adaptação também corporal imposta pela nova condição de vida, fato este que se traduzia no vestir.

Meu marido me fez perder este hábito, explicando que não era bom consumir muito sal em clima quente. Certamente ele estava certo, pois tive problemas de aclimatização, tendo muita coceira em conseqüência de furúnculos nos pés. Eu não conseguia calçar sapatos e mancava em tamancos de couro cujas pontas, como num lamento, apontavam para o céu. Ao acordar, as dores, o formigamento e as pontadas nos pés eram bastante desagradáveis até me movimentar, então se tornava mais suportável até que um movimento mais brusco provocava novamente dor. Os banhos 
com água morna e sabão sempre aliviavam. Mas isto também passou. O sangue consistente e a gordura alemã precisavam se adaptar, eu emagreci muitos quilos e, mais tarde, adquiri a tão em moda figura esbelta (HERMANN, 2003, p.21-22).

O desuso do calçado na vida quotidiana dos colonos é também exemplo de uma alteração no hábito vestimentar destes. No relato anterior o desconforto aparece como um motivo possível para este descarte, já a sensação de liberdade que tal condição garantia, no caso particular das crianças, apresenta-se na carta escrita por Thereze Stutzer falando de sua filha, no ano de 1886:

Lá vem minha pequenina e vejo que ela está descalça. Seu maior prazer é tirar as meias e os sapatos para andar livremente. Todas as suas amiguinhas o fazem e Eva as imita. "Mas, minha filha, tu és uma menina alemã!". Ela sacode a cabeça e lá se vai, e nós então precisamos alcançá-la. Isto aqui é um verdadeiro paraíso para crianças! Elas sempre podem estar ao ar livre! As crianças não precisam de sapato, nem de meias, basta uma blusinha e uma saia (STUTZER, 2002, p. 94).

Assim como se reservavam os vestidos de seda para as ocasiões especiais, os sapatos, para quem os possuía, eram igualmente usados nas visitas as vilas ou cidades próximas, pois o seu uso estava condicionado à urbanização e "descalço o colono se sentiria repelido e humilhado por uma sociedade que associava à ausência do sapato o estigma da miserabilidade" (WILLEMS, 1946, p.236).

Além dos depoimentos colhidos nas cartas e memórias, usou-se ainda o suporte das fotografias como fontes históricas para a análise das práticas vestimentares em Blumenau.

\subsubsection{Fotografias}

Entendendo a fotografia como um produto social que "coloca em cena questões e fragmentos da história" (CANABARRO, 2005, p.24) propõe-se analisar as descrições apresentadas a partir da imagem fotográfica, ou seja, considerando-a uma fonte de pesquisa ${ }^{3} \mathrm{e}$ não somente ilustração do texto verbal.

As duas fotografias selecionadas encontram-se para acesso de pesquisadores no acervo do Arquivo Histórico José Ferreira da Silva da cidade de Blumenau e são doações de moradores conscientes da necessidade de preservação do patrimônio cultural da cidade.

\footnotetext{
${ }^{3}$ Sabe-se que há uma metodologia adequada e completa para tal análise, entretanto neste estudo as fotografias foram pensadas como um ponto de comparação entre os relatos das memórias, das cartas, da literatura a respeito das tendências de moda da época e, no próximo capítulo, das peças reais do acervo museológicos. Assim que, não se esgotam todas as possibilidades de estudo dessas fotos, pelo contrário, se utiliza das mesmas com um foco bastante especifico.
} 
A primeira fotografia retrata oito mulheres da sociedade envoltas pela exuberância da flora local nas primeiras décadas de fundação de Blumenau. Vestem corpete com decote de ombro a ombro ou em forma triangular ornados por rendas ou com gola sobreposta, terminados com a barra reta e presos por um cinto. As saias são amplas e franzidas na cintura, se armadas pela crinolina de forma circular ou por anáguas, não se pode precisar. Cabelos repartidos no meio com coques presos na parte de trás da cabeça e longas tranças ao redor.

Fica evidente, na imagem fotográfica, que os trajes usados no segundo quinquênio do século XIX correspondiam aos padrões de tendências de moda do início do século. Padrão este descrito por Laver (2003) como romântico e extravagante, tendo como traços maiores o decote de ombro a ombro com mangas curtas e fofas, a saia ampla e a cintura fina é marcada na altura do umbigo.

Figura 1 - Imagem fotográfica: mulheres da sociedade da Blumenau Colônia. Início da colonização. Acervo do Arquivo Histórico José Ferreira da Silva.

Já a segunda figura corresponde às últimas décadas do século XIX e apresenta treze mulheres da sociedade colonial seguindo os padrões das tendências de moda do segundo qüinqüênio do século, que Laver (2003) descreve como mais simples, mesmo que aos olhos modernos pareçam ainda pomposos, caracterizado pela saia terminada em cauda tendo a ela acrescida a sobre-saia drapeada e armada atrás em uma anquinha ou com algumas mudanças ao longo das décadas, mas em geral, valorizando a cintura marcada e o volume alto na saia.

As senhoras vestem corpete acinturado com a frente terminada em forma de triângulo, gola em pé e peitilho de tecido diferente do corpete. Manga justa no punho e alta e franzida no ombro. Saia com volume alto nas costas e a frente reta. Tecidos com padronagens de listras e xadrez. Permanecem os cabelos separados no meio com coques altos na cabeça, mas sem as 
tranças. Uso de acessórios como broches na gola ou correntes no pescoço e chapéu com abas curtas atrás se projetando na frente e levemente nas laterais, adornado por tules e flores.

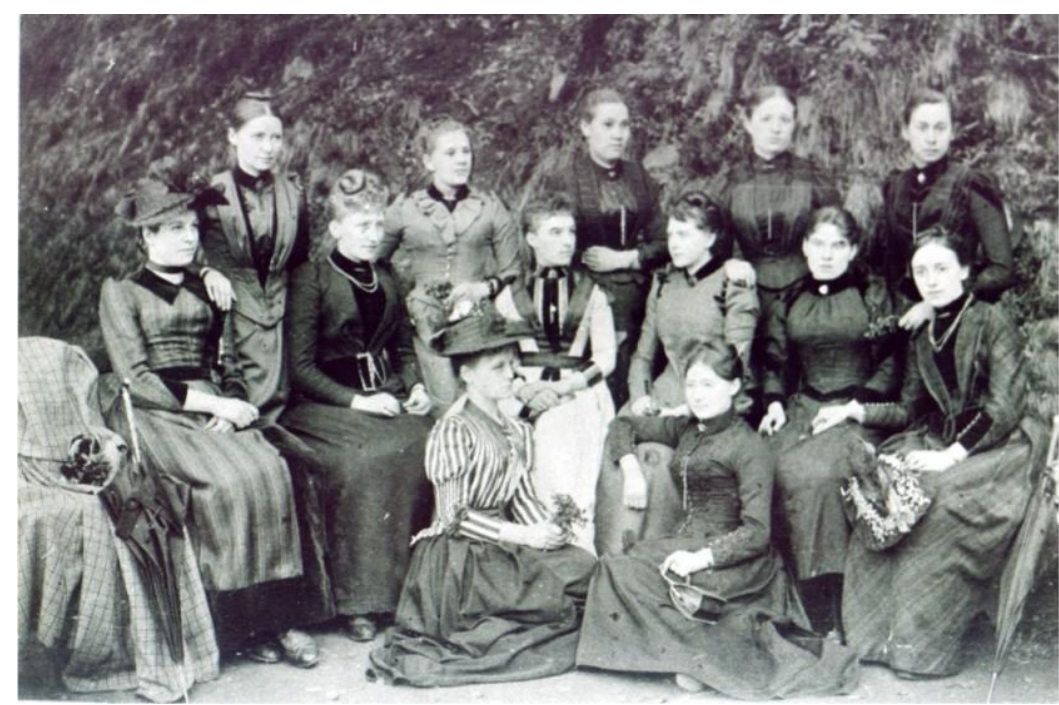

Figura 2 - Imagem fotográfica: mulheres da sociedade da Blumenau Colônia. Final do século XIX. Acervo do Arquivo Histórico José Ferreira da Silva.

Como se pode verificar nas fotografias as mulheres de Blumenau seguiam, mesmo que tardiamente, as tendências de moda européias e com certa redução no luxo e na quantidade de tecido e ornamentos usados. No entanto, resta compreender de que maneira elas reformavam suas roupas ou confeccionavam novas peças com os olhos voltados para o novo, onde elas conheciam este novo e como este chegava até o conhecimento dessas mulheres.

\subsection{INFORMAÇÃO DE MODA}

O espelho europeu de consumo chegava ao Rio de Janeiro através das crônicas dos jornais e das revistas, vinculadas por periódicos cujos nomes já denotavam o público-alvo feminino. Mulheres educadas, freqüentadoras do espaço público das ruas, ávidas por informações sobre as novidades das tendências de moda e sobre a adequação das vestimentas as diversas ocasiões, era para estas leitoras que o espelho de uma elegância e civilidade à la européia ficava a serviço (RAINHO, 2002).

Estes veículos de comunicação, porta-vozes das tendências de moda lançadas na França e Inglaterra, principalmente, também tinham a função de evidenciar a importância da exibição pública divulgando notas, semanais ou quinzenais, de bailes e episódios recém acontecidos. Além disso, propagandas dos inúmeros produtos importados, ilustradas ou não, 
desenhavam e propagavam uma forma de ser mulher criada na Corte e idealizada nos moldes estrangeiros.

No caso de Blumenau, as mulheres liam também os periódicos femininos impressos em Berlim, que hoje constam no acervo do Arquivo Histórico José Ferreira da Silva na cidade de Blumenau. As revistas analisadas, assim como as lidas pelas cariocas, traziam no nome quem eram as leitoras e o conteúdo: "Die Modenwelt" (A Moda no Mundo) e "Victoria Illustrierte Muster und Modezeitung" (Victória-Jornal de Moda e Modelos Ilustrados). As edições constantes no acervo e encadernadas em um mesmo livro são quinzenais e referentes às décadas de 60 e 70. Nas páginas ricamente ilustradas o idioma é o alemão gótico e a não compreensão dos textos resume o estudo a análise do imagético ${ }^{4}$.

As roupas apresentadas são por vezes retratadas vestindo as mulheres ou sozinhas com destaque maior para as peças, em ambos os casos, são divididas em categorias, como: corpetes, vestidos, saias, conjuntos, punhos, golas, manta, roupa de baixo, roupa infantil... Duas vezes a cada mês na revista "Victoria" há uma página especifica pra uma ilustração colorida.
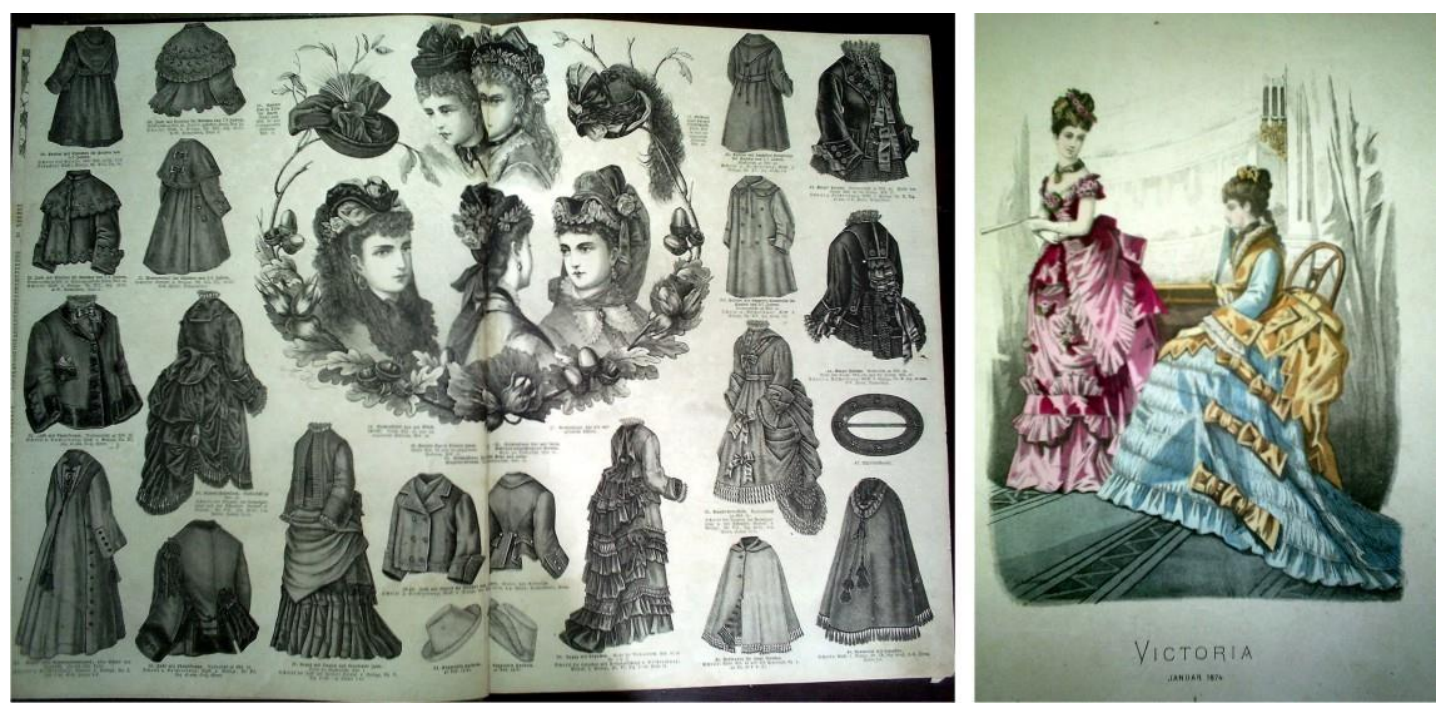

Figura 3 - Ilustração de peças variadas e ilustração colorida.

Fonte: (MODENWELT, 1868) e (VICTORIA, 1874).

Técnicas de bordado com o passo a passo, crochê, tricô e macramé com os gráficos e materiais específicos e outras tantas técnicas para fazer os babados, as flores, os franzidos e todos os outros enfeites tão em voga no período.

\footnotetext{
${ }^{4}$ Tem-se consciência, assim como no caso do estudo das fotografias, que há metodologia apropriada para a análise das revistas. Por exemplo, a exploração do suporte no qual as imagens são reproduzidas, o traço do artista que as ilustrou, as possibilidades técnicas da época, a recepção do leitor, entre outras. Porém, estas não são preocupações desse estudo, e sim um embasamento comparativo e ilustrativo de como as informações de moda chegavam as mulheres imigrantes.
} 

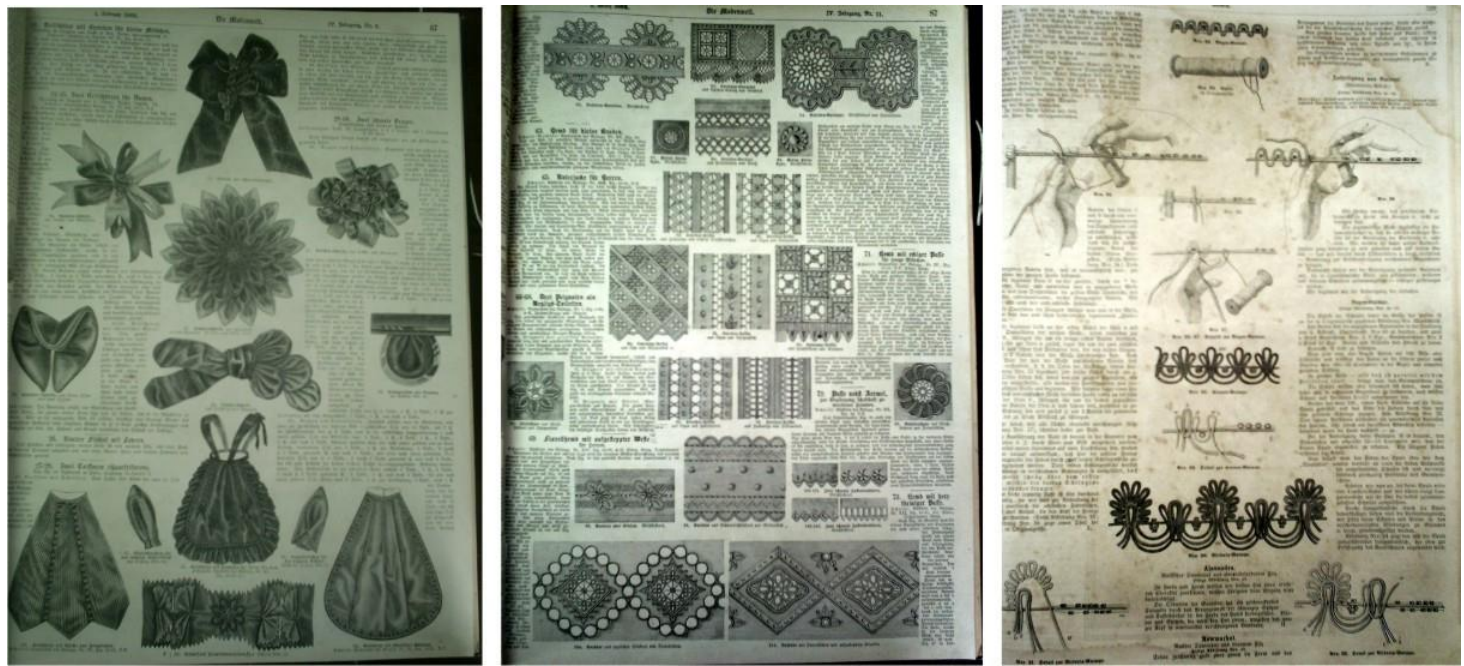

Figura 4 - Técnicas variadas.

Fonte: (MODENWELT, 1869a, p.67), (MODENWELT, 1869b, p.87) e (VICTORIA, 1863a, p.329).

Acessórios como bolsas e sapatos também constam nas revistas, inclusive ensinando a confeccioná-los de tricô ou crochê. Bem como chapéus, sombrinhas e ainda bolsas utilitárias com divisórias diversas para guardar desde objetos de costura, até pentes e escovas. Há ainda acessórios para a casa como cortinas, toalhas, almofadas, entre outros.

Figura 5 - Acessórios: bolsa utilitária e sombrinhas.

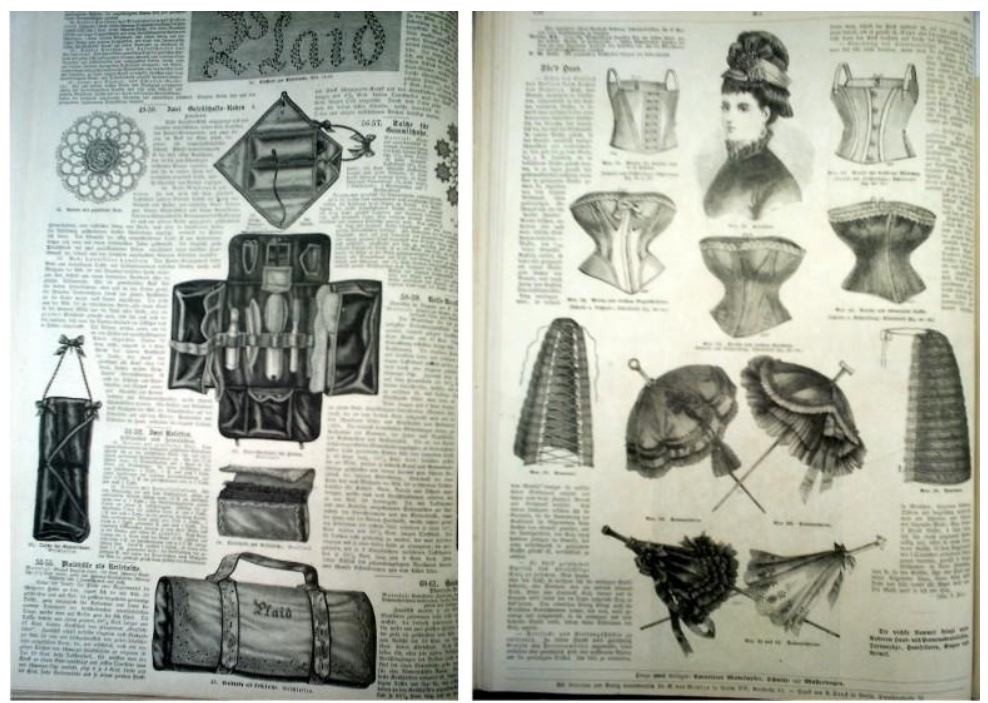

Fonte: (MODENWELT, 1989c, p.100) e (VICTORIA, 1874b, p.136).

Destaque também para as ilustrações dos penteados com cachos e amarrações bastante elaboradas. Tendências românticas de um parecer que dispunha de um arsenal vasto de artifícios. 


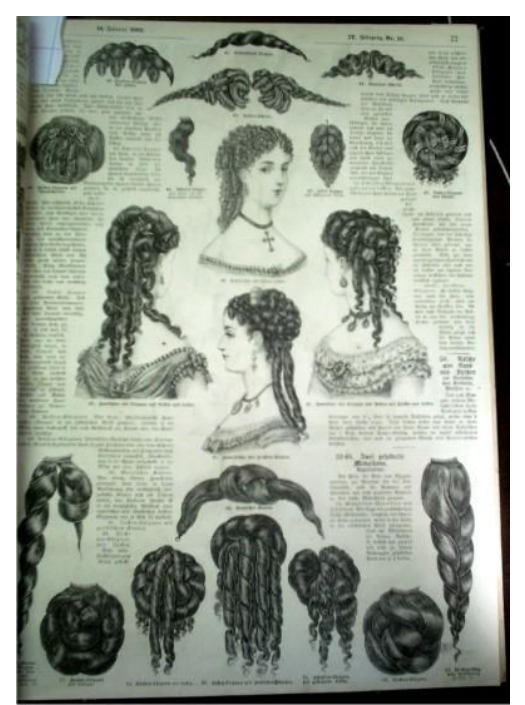

Figura 6 - Penteados.

Fonte: (MODENWELT, 1869d, p.67).

Constavam em todas as revistas contos literários, que provavelmente continuavam a cada próxima edição, e partituras de música, ambos são emblemas de um universo feminino centrado no lar e na família.
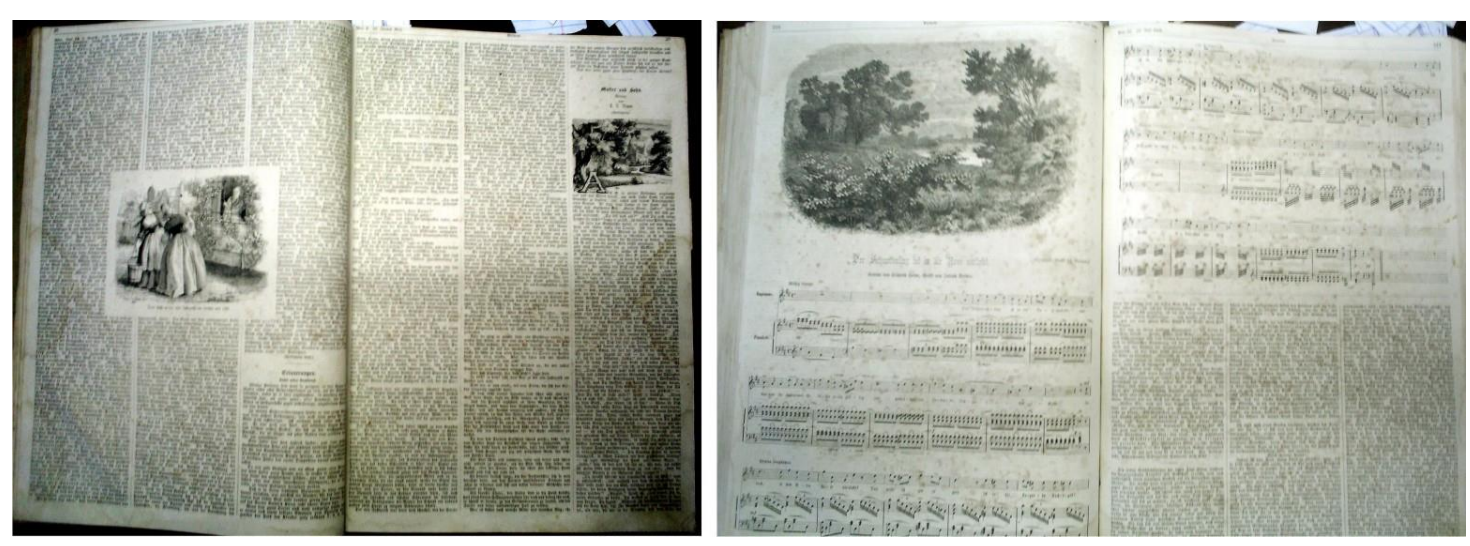

Figura 7 - Romances e Partituras.

Fonte: (VICTORIA, 1863b, p.28-29) e (VICTORIA, 1863c, p.216-217).

Percebe-se que o ideal de mulher e de consumo que se apresentava nas revistas de Berlim eram os mesmos das revistas adquiridas no Rio de Janeiro. Logo, as mulheres em Blumenau que liam estas revistas tinham acesso à informação de moda semelhante das cariocas, mas é provável que com grande atraso em relação ao lançamento destas. Mostra-se evidente a dicotomia entre o conteúdo das revistas e as possibilidades de uso em Blumenau, porém, as informações de moda são sempre referências e por não corresponderem, necessariamente, aos padrões reais de usos e consumos não deixam de ser janelas para o entendimento desta sociedade. 
As revistas tinham ainda um importante papel na "formação de estruturas mentais favoráveis a moda" (MAUAD, 1997, p.202), pois era um espaço fundamental para a divulgação do novo e a sua transformação em algo corriqueiro. Contudo, o novo precisava de um palco de exibição eficiente, portanto, resta investigar os espaços de sociabilidade disponíveis em Blumenau.

\subsection{ESPAÇOS DE SOCIABILIDADE}

No Rio de Janeiro e em outros locais que tiveram surtos econômicos seguindo o espelho da Corte européia, tornaram-se comuns os passeios pelas ruas do comércio, as festas nos cassinos, os saraus e os bailes nas mansões da elite local e os veraneios nos arredores da cidade. Já em Blumenau os momentos de lazer eram poucos e restritos aos encontros familiares, as reuniões das associações e à igreja (especialmente o culto dominical). Sendo que, ambas as atividades agregavam valores como a preservação do idioma e dos costumes, integração social e a troca de experiências para a adaptação ao novo meio (PETRY, 2007).

Em carta escrita em 1886 a imigrante não esconde a dificuldade de se afastar da vida cultural oferecida na Alemanha e revela que as atividades diárias em Blumenau visavam apenas o lucro, fato que a entristecia:

\footnotetext{
Sabes que a impossibilidade de viajar realmente nos incomoda. O "Progresso" vem duas vezes por semana, e te digo que ainda estremeço quando escuto seu apito, porque me faz lembrar que é nosso elo com a pátria. Fico pensando o que será que nos aflige - é um sentimento vago -, mas é a falta de vida cultural. Lá, inconscientemente respirávamos cultura, enquanto aqui o materialismo nos cerca. $\mathrm{Na}$ Alemanha se vive do passado para o futuro. Aqui se vive somente para o presente, porque o país ainda não tem passado e ninguém precisa se preocupar com o futuro. Costumes, direitos, origem, velhas tradições, são atributos que fazem parte da vida dos alemães. Lá, até as pedras contam histórias, as velhas árvores sussurram lendas já quase esquecidas, a poesia envolve nosso inconsciente... e aqui? O lucro com certeza é útil, mas, se o fator preponderante de toda a atividade apenas visar este aspecto e a única preocupação for o lucro, isto nos entristece. Em relação a isso poderia se empregar as palavras do "Salvador": "nem só de pão vive o homem". Afinal, o belo, sob o qual entendo tudo aquilo que eleva nossos sentidos e que alimenta o espírito, não é necessário para o desenvolvimento do ser humano? (STUTZER, 2002, p.100).
}

A rudeza do trabalho, a saudade e a seriedade da vida eram compensadas pelas relações calorosas entre os alemães travadas no seio de sociedades culturais e esportivas. Aliadas ao espírito associativo alemão foram fundadas diversas sociedades: em 1863 duas associações de canto, em 1869 a União dos Cantores e a Kultur-Vereine onde se discutiam problemas relativos ao setor produtivo, em 1870 a Sociedade dos Atiradores começou a 
construir a sua própria sede, a qual foi dotada de um palco onde aconteciam apresentações teatrais e em 1873 a fundação da associação de ginástica (RENAUX, 1995). As palavras do colono demonstram a relevância social destes grupos:

\begin{abstract}
Elas são, em certo sentido, documentos culturais, vindo em primeira linha as Sociedades de Canto, Ginástica e de Caça e Tiro. Cada uma das citadas sociedades muito fez pela disseminação da cultura alemã, pois, por meio da atividade, canto e pela palavra conservaram no povo os costumes e os ideias, os quais nossos poetas e filósofos nos legaram, preservando-nos contra o materialismo dos tempos atuais (BRUECKHEIMER apud RENAUX, 1995: 108).
\end{abstract}

A mais marcante atividade cultural de Blumenau era o teatro e a história da sua implantação liga-se à vida de Roese Gaertner, nascida na Silésia, Alemanha, em 1842. No ano de 1860, já residindo em Blumenau escreveu aos seus parentes: "para os que gostam de vida cultural, naturalmente essa não existe aqui” (apud RENAUX, 1995, p. 151). Motivada por esta constatação antecipou em casa a vida cultural sonhada, em sua residência ela dançava "ao som de um violino ou de uma harmônica que substituem os coros e as orquestras da Alemanha" (GAERTNER apud RENAUX, 1995, p. 151).

Em 1870, nas novas dependências da sede da Sociedade dos Atiradores (Schützenhaus), construiu-se um palco onde aconteciam encenações teatrais, nas quais a protagonista principal era Roese Gaertner. Na busca por maior profissionalização da prática teatral empenhou-se em uma campanha que culminou na construção de uma sede própria para o seu grupo teatral chamada Theaterverein Frohsinn (Sociedade Teatral Bom Humor) e em 1896 apresentou a primeira peça (RENAUX, 1995).

Nas palavras do colono Gustav Stutzer a descrição das atividades realizadas na Sociedade dos Atiradores retificando a importância do teatro como forma de convívio social e os bailes que seguiam as apresentações:

\footnotetext{
O centro da vida social é o Schützenhaus na cidade de Blumenau. Ali toda a segunda-feira se reúne a sociedade de senhores e autoridades para o bolão, o infalível skat e a conversa informal (...). No Schützenhaus acontecem apresentações teatrais (...). Principalmente em pequenas peças de comédia apresentavam valiosos espetáculos. Também os cenários eram vistosos e pintados aqui mesmo. Após estas apresentações teatrais acontecia um baile, abrilhantado pela orquestra Rüdiger. As mulheres quase sempre compareciam vestidas de branco. Nossos patrícios em Blumenau realmente gostam de dançar. Um curso de dança é anualmente apresentado para a juventude (apud RENAUX, 1995, p.152).
}

Outro lazer, tal como difundido na Europa, eram as atividades junto à natureza. Em carta escrita em 1889 Therese Stutzer, esposa de Gustav, conta do dia agradável que passou com os amigos em um piquenique: 


\begin{abstract}
Vou falar do piquenique que fizemos esta semana na Velha. Esteve ótimo! Foi sugestão de Gustav, pois o tempo estava muito bom. Eu comentei o assunto com a sra. Sch. E ela achou uma boa idéia. Convidamos mais trinta pessoas. Quando Eva, eu e as empregadas chegamos lá com a louça do café, já havia uma fogueira à sombra da figueira, sob a qual pendia, de um galho de bambu, uma chaleira com água fervente. (...) Realmente estava maravilhoso. As charretes, os cavalos, as mulheres em seus vestidos em tons claros, tudo isto, neste ambiente iluminado pela fogueira, era uma visão singular que jamais esquecerei. Nós nos divertimos muito. Enquanto fazíamos um passeio de reconhecimento pela mata, as crianças cantavam (STUTZER, 2002, p. 104).
\end{abstract}

Em ambos os relatos apresentou-se a preocupação em sinalizar as roupas usadas e o fato destas serem em cores claras. Tal comentário revela a importância do uso de trajes adequados para as ocasiões de lazer e como, apesar de escassos, estes momentos eram espaços não somente para manter os laços com a velha pátria, mas também espaço para a experiência estética na socialização e observação do outro e exibição de si.

\title{
1.5 ARREMATANDO OS PONTOS
}

Neste artigo, pode-se pensar a respeito das práticas vestimentares das colonas alemãs em Blumenau em comparação com a Europa e o Brasil, a partir de informações de fontes escritas, fotografias e ilustrações de revistas.

Sabe-se que a dificuldade econômica era dos maiores motivadores da migração, assim que, a colona, já na Alemanha, estava afastada do luxo da vida aristocrática e já trazia em sua bagagem o hábito do trabalho. Na nova pátria, as imigrantes viram-se obrigadas a aprender a costurar para, se não confeccionar peças novas, restaurar as roupas da família. E é nos relatos dessa necessidade que se percebe que uma mesma roupa era usada por muitos anos e, provavelmente, por muitas mulheres diferentes.

Fato este, que deve ser acrescido ao tempo de demora para que as peças novas chegassem da Europa, com o objetivo de se ampliar o entendimento do atraso no uso das tendências de moda européias.

Dentro dos limites apontados neste artigo, revelaram-se adaptações e mudanças nos usos e nas sociabilidades das imigrantes alemãs e das gerações seguintes. Estas, especialmente, relacionadas com a nova realidade geográfica com a qual elas se deparavam. $\mathrm{O}$ clima subtropical, a dificuldade de acesso a região, o transporte deficitário... Situações que impõem um vestir mais prático, simples e confortável. 


\section{REFERÊNCIAS}

BAUDRILlARD, Jean. O sistema dos objetos. 4 ed. São Paulo: Perspectiva, 2000.

CABRAL, Oswaldo R. Nossa Senhora do Desterro. Vol.1 Florianópolis: Lunardelli, 1979.

CANABARRO, Ivo. Fotografia, história e cultura fotográfica: aproximações. In: Estudos Ibero-Americanos. PUCRS, v. XXXI, n.2, p.23-39, dezembro 2005.

CONSONI. Paula. Moda em acervos: estudo da sociedade blumenauense de 1850-1890 a partir de vestígios de seu vestir. Florianópolis: 2008. Trabalho de conclusão de curso (Moda). UDESC. (orientadora: Profa. Dra. Mara Rúbia Santa'Anna). 99p.

CONSONI. Paula e SANT'ANNA, Mara Rúbia. Feminilidade e consumos no Brasil Imperial. In: SIMPÓSIO NACIONAL DE HISTÓRIA, 14., 2007, São Leopoldo. 1 CDROM.

CONVERSA de um velho colono Blumenauense. Blumenau em Cadernos, Blumenau, t.XLVIII, n.3/4, mar./abr. 2007.

CHARLOT, Claire. Harrod's, o altar da moda. In: Londres, 1851-1901: a era vitoriana ou o triunfo das desigualdades. Rio de Janeiro: Jorge Zahar, 1993.

HERMANN, Karla. As vivências de Karla Hermann. Tradução: Annemarie Fouquet Schünke. Blumenau em Cadernos, Blumenau, t.XLIV, n.1/2, jan./fev. 2003.

KLEINE, Karl. A chegada em Blumenau. Tradução: Brigitte Kretzschmar. Blumenau em Cadernos, Blumenau, t.XLI, n.11/12, nov./dez. 2000.

LAVER, James. A roupa e a moda: uma história concisa. $7^{a}$ reimp. São Paulo: Companhia das Letras, 2003.

MACEDO, Joaquim Manuel de. Memórias da Rua do Ouvidor. [S.I.]: Biblio. Disponível em: <http://www.biblio.com.br/conteudo/JoaquimManueldeMacedo/

memoriasdarua.htm>. Acesso em: 10 jun. 2007.

MAUAD, Ana Maria. Imagem e auto-imagem do segundo reinado. In: História da vida privada no Brasil: Império: a corte e a modernidade nacional. Vol. 2 São Paulo: Companhia das Letras, 1997.

MAURO, Frédéric. O Brasil no tempo de Dom Pedro II: 1831-1889. São Paulo: Companhia das Letras, 1991. 
MEYER, Franz. Carta [a irmã e cunhado na Alemanha]. Colônia Blumenau, 1862. Arquivo Histórico José Ferreira da Silva. Fundo memória da cidade. Coleção famílias. Família Meyer, 3.M.10. doc.3. 1862

MEYER, Franz. Carta [a irmã e cunhado na Alemanha]. Colônia Blumenau, 1863. Arquivo Histórico José Ferreira da Silva. Fundo memória da cidade. Coleção famílias. Família Meyer, 3.M.10. doc.4. 1863.

MEYER, Franz. Carta [a irmã e cunhado na Alemanha]. Colônia Blumenau, 1867. Arquivo Histórico José Ferreira da Silva. Fundo memória da cidade. Coleção famílias. Família Meyer, 3.M.10. doc.5. 1867.

MEYER, Franz. Carta [a irmã e cunhado na Alemanha]. Colônia Blumenau, 1887. Arquivo Histórico José Ferreira da Silva. Fundo memória da cidade. Coleção famílias. Família Meyer, 3.M.10. doc.8. 1887.

PETRY, Sueli Maria Vanzuita. Na trama do cotidiano: a indumentária oitocentista em Blumenau (1850-1880). Blumenau em Cadernos, Blumenau, t.XLVIII, n.11/12, nov./dez. 2007.

RAINHO, Maria do Carmo. A cidade e a moda. Brasília: UNB, 2002.

RENAUX, Maria Luiza. O papel da mulher no Vale do Itajaí, 1850-1950. Blumenau: FURB, 1995.

SALLENTIEN, Franz. Carta do imigrante Franz Sallentien, 1855. Tradução: Alda Niemeyer. Blumenau em Cadernos, Blumenau, t.XXXVIII, n.4, abr. 1997.

SAMETZKY, Rose. Carta [aos avós na Alemanha]. Colônia Blumenau, 1860. Arquivo Histórico José Ferreira da Silva. Fundo memória da cidade. Coleção famílias. Família Gaertner, 3.G.13.doc.3.1860.

SANT'ANNA. Mara Rúbia. Teoria de Moda: sociedade, imagem e consumo. Barueri: Estação das Letras, 2007.

SANTIAGO, Nelson Marcelo; PETRY, Sueli Maria Vanzuita; FERREIRA, Cristina. ACIB: 100 anos construindo Blumenau. Florianópolis: Expressão Sul, 2001.

SOUZA, Gilda de Mello e. O espírito das roupas: a moda no século dezenove. São Paulo: Companhia das Letras, 1987.

STUTZER, Thereze; Huber, Valburga (Org.). Tradução: Valburga Huber. Marie Luise. Blumenau: Cultura em Movimento, 2002.

WILLEMS, Emilio. A cultura dos alemães no Brasil: estudo antropológico dos imigrantes alemães e seus descendentes no Brasil. Companhia Editora Nacional, 1946. 


\section{PERIÓDICOS}

Die Modenwelt. Berlim. 1868.

Die Modenwelt. Berlim. 1869a. 1 fev. p.67.

Die Modenwelt. Berlim. 1869b. 1 mar. p.87.

Die Modenwelt. Berlim. 1869c. 1 maio. p.100

Die Modenwelt. Berlim. 1869d. 16 fev. p.67

Victoria - Illustrierte Muster und Modezeitung. Berlim. 1863a. 15 nov. p.329

Victoria - Illustrierte Muster und Modezeitung. Berlim. 1863b. 22 jan. p.28-29

Victoria - Illustrierte Muster und Modezeitung. Berlim. 1863c. 22 jul. p.216-217

Victoria - Illustrierte Muster und Modezeitung. Berlim. 1874b. 1 maio. p.136 